\title{
Community structure and floristic composition of Quercus fusiformis and Carya illinoinensis forests of the Northeastern Coastal Plain, Coahuila, Mexico
}

\author{
Estructura y composición florística de los bosques de Quercus fusiformis y Carya illinoinensis de \\ la planicie costera del noreste, Coahuila, México
}

\author{
Juan Antonio Encina-Domínguez ${ }^{*}$, Efrén Mata Rocha ${ }^{1}$, Jorge A. Meave ${ }^{2}$ and Alejandro Zárate-Lupercio ${ }^{1}$ \\ IDepartamento Forestal, Laboratorio de Sistemas de Información Geográfica. Universidad Autónoma Agraria Antonio Narro, Calzada Antonio Narro, \\ Núm. 1923, Buenavista, 25315 Saltillo, Coahuila, México. \\ ${ }^{2}$ Departamento de Ecología y Recursos Naturales, Facultad de Ciencias, Universidad Nacional Autónoma de México, 04510, México D.F., México. \\ "Correspondent: juanencina@gmail.com
}

\begin{abstract}
In order to describe community structure and richness in oak and walnut forests occurring along the San Rodrigo, San Diego, Escondido and Arroyo de las Vacas rivers on the Northeastern Coastal Plain (NE Coahuila, Mexico), we established $301000-\mathrm{m}^{2}$ circular plots, where we measured diameter at breast height (DBH) and tree heights. Tree regeneration and herb and shrub stratum were assessed in $52-\mathrm{m}^{2}$ quadrats per site. A total of 48 species distributed in 29 families were recorded. Families with the largest richness were Poaceae, Asteraceae, and Malvaceae. For the oak forest, tree stratum density and basal area values were $386 \mathrm{stems} /$ ha and $24.36 \mathrm{~m}^{2} / \mathrm{ha}$, respectively, whereas for the walnut forest the corresponding values were $302 \mathrm{stems} / \mathrm{ha}$ and $21.26 \mathrm{~m}^{2} / \mathrm{ha}$. The species with the highest relative importance values were Quercus fusiformis (59.48\%) and Carya illinoinensis (57.58\%). Total tree richness was 14 species, the most common ones being Celtis reticulata and Diospyros texana, followed closely by C. illinoinensis and Q. fusiformis. Anthropogenic impact appears to result in a poor regeneration reflected as a low sapling density, as well as in the reduction and fragmentation of these communities; in turn, this process has led to intrusions of species typical of the xerophytic Tamaulipan Thorn Scrub. Further studies are needed on the regeneration of the dominant species of these forests in order to describe their dynamics and to promote their preservation.
\end{abstract}

Key words: basal area, forest regeneration, oak forest, species invasions, tree density, walnut forest.

Resumen. Con la finalidad de conocer la estructura y la composición florística de los bosques de encino y nogal situados a lo largo de los ríos San Rodrigo, San Diego, Escondido y Arroyo de las Vacas en la planicie costera nororiental (NE de Coahuila, México), se establecieron 30 parcelas circulares de $1000 \mathrm{~m}^{2}$ en las que se midió el DAP y la altura de las especies arbóreas; además, se evaluó la regeneración de las especies arbóreas y el estrato herbáceo y arbustivo en 5 cuadros de $2 \mathrm{~m}^{2}$ por sitio. Se registraron 48 especies, integradas en 29 familias, siendo Poaceae, Asteraceae y Malvaceae las de mayor riqueza. La densidad y el área basal para el estrato arbóreo del bosque de encino fueron 386 ind/ha y $24.36 \mathrm{~m}^{2} / \mathrm{ha}$, mientras que los valores respectivos para el bosque de nogal fueron $302 \mathrm{ind} / \mathrm{ha} \mathrm{y} 21.26 \mathrm{~m} / \mathrm{ha}$. Las especies con los mayores valores de importancia fueron Quercus fusiformis y Carya illinoinensis, con 59.48\% y $57.58 \%$, respectivamente. La riqueza arbórea fue de 14 especies; las más frecuentes fueron Celtis reticulata y Diospyros texana, seguidas de C. illinoinensis y Q. fusiformis. El impacto antropogénico ha ocasionado que la regeneración y el arbolado juvenil tengan densidades bajas, y ha reducido y fragmentado estas comunidades, lo que ha permitido la colonización de especies xerófitas del matorral tamaulipeco. Es necesario realizar estudios sobre la regeneración de las especies para conocer su dinámica y garantizar la conservación de estas comunidades.

Palabras clave: área basal, bosque de encino, bosque de nogal, densidad de los árboles, invasión de especies, regeneración del bosque.

\section{Introduction}

In the northern Mexican State of Coahuila, riparian semievergreen forests ('bosques subperennifolios ribereños'

Recibido: 09 marzo 2010; aceptado: 13 septiembre 2010 sensu Lot and Novelo, 1990) occur along riverbanks in the eastern watershed of the El Burro Range. Despite the lack of adequate cartography, these communities appear to have a very restricted and irregular distribution; they are dominated by Carya illinoinensis (Wang.) K.Koch (walnut or 'nogal' in Spanish), a very common species in deciduous forests of southeastern USA (Correll and Johnston, 1970). In Mexico, trees of this species are common in forest communities 
located in the vicinity of rivers in northeastern Coahuila (Johnston, 1944; Villarreal-Quintanilla et al., 2006), whilst in Nuevo León they have been reported to form part of temperate deciduous forests (Alanís et al., 1996), or of gallery forests (Treviño et al., 2001). Further common genera in these forests are Quercus, Morus, Platanus, Fraxinus, Juglans, and Prosopis (Villarreal-Quintanilla and Valdés-Reyna, 1992-93; Villarreal-Quintanilla et al., 2006).

Similarly, the only region of Mexico where oak forests dominated by Quercus fusiformis Small occur is in northeastern Coahuila, where they cover less than $1 \%$ of the state's territory (Anonymous, 2001). These communities are also present on the Coastal Plain of Texas and on the Edwards Plateau, west of the Pecos River (Muller, 1951; Correll and Johnston, 1970; Fowler, 1988). Relict populations of this species are patchily distributed along intermittent creeks and ravines in Coahuila's eastern corner (Encina-Domínguez and Villarreal-Quintanilla, 2002), in central and northeastern Nuevo León (Valdés and Aguilar, 1983; Marroquín, 1985), as well as in the San Carlos Range, Tamaulipas (Briones, 1991). Rzedowski (1978) described low elevation $(\mathrm{ca} .350 \mathrm{~m})$ communities dominated by this species located to the southwest of Piedras Negras.

The estimated total area occupied by these forest communities in Coahuila is 44629 ha (equivalent to $1.84 \%$ of the state's territory), of which 23039 ha $(0.95 \%)$ correspond to oak forest, and the remaining 21590 ha $(0.89 \%)$ to riparian vegetation (Anonymous, 2001). Among the most important environmental services provided by these forests are erosion prevention and the filtering of sediments, nutrients, and pollutants, which ultimately improves water quality (Patten, 1998), along with their role as habitat for wild fauna (Solís and Jenkins, 1998). Unfortunately and in spite of these benefits, these forests are continuously subjected to irrational human practices, ranging from conversion into pastures for cattle raising, timber extraction, mining of construction materials, and the building of reservoirs (Villarreal-Quintanilla et al., 2006). Motivated by this situation, the aim of this study was to provide information on the structure, floristics, and diversity of oak ( $Q$. fusiformis) and walnut (C. illinoinensis) forests growing in the northeastern Gulf of Mexico coastal plain, NE Coahuila. The ultimate goal was to provide a sound synecological basis for future studies examining their dynamics and to contribute to their conservation.

\section{Materials and methods}

The study area is located along the San Rodrigo, San Diego, Escondido, and Arroyo de las Vacas rivers in northern Coahuila, and it includes portions of Acuña, Jiménez,
Piedras Negras, and Zaragoza counties (Fig. 1). This region is part of the Great North American Plains physiographic province (Anonymous, 1983), known in Mexico as the Gulf Coast Plain morphotectonic province (FerrusquíaVillafranca, 1993). More precisely, it corresponds to the northern portion of the Northeastern Coastal Plain (Rzedowski, 1978), which includes the northern and eastern sectors of Nuevo León State, the whole territory of Tamaulipas State, northeastern Coahuila, and adjacent portions of Texas (González-Medrano, 1985). In Coahuila, the area included within this physiographic province is 25 $665 \mathrm{~km}^{2}$; its northern limit is the Rio Bravo (known as Rio Grande in the USA) and to the west it abuts with the Sierra Madre Oriental; the region is characterized by wide-open plains, occasionally broken by scattered gently rolling hills with elevations ranging from 250 to $500 \mathrm{~m}$ asl. This zone is part of the RH-24 "Bravo-Conchos" hydrologic region, within the Rio Bravo-Piedras Negras Basin, which encompasses intermittent streams and a few isolated rivers that flow mostly from the El Burro Range (Anonymous, 1983). The climate is of the $\mathrm{BS}_{0} \mathrm{~h}(\mathrm{x})$ type, i.e., dry, warm to semi-warm, with mean annual temperature $>22^{\circ} \mathrm{C}$ and wide thermal fluctuations (Anonymous, 2001); mean total annual precipitation fluctuates from 350 to $500 \mathrm{~mm}$ and is evenly distributed throughout the year. The oldest rocks found in the parental bedrock are associations of lutitessandstones and limestone-lutites of Upper Cretaceous age. The clayey, alluvial soils are alkaline and they include a limestone layer in the subsoil; their color is brown or gray and they have low organic matter contents. The most extensive soil units are Calcic xerosols, Haplic xerosols and Calcaric regosols of medium texture; on the hills medium-textured Lithosols prevail that may be associated to varying degrees with calcaric regosols (Anonymous, 2001).

From a floristic viewpoint, this region is considered part of the Northeastern Coastal Plain Province, which in Mexico covers almost the entire territory of Tamaulipas, the northeastern third of Nuevo León, and the northeastern sector of Coahuila (Rzedowski, 1978). Despite its northern location in the country, the region has strong links with southern floras, although it also hosts a considerable number of species with restricted distributions (Rzedowski, 1965). The Tamaulipan Thorn Scrub is the prevailing vegetation in NE Coahuila (Muller, 1945); however, in areas with higher moisture availability and deeper soils other plant communities occur, such as mesquite forests, riparian vegetation, and oak forests (Rzedowski, 1978; VillarrealQuintanilla and Valdés-Reyna, 1992-93).

We estimated community-level variables by sampling the vegetation at 30 sites: 9 of them were on the Arroyo de las Vacas river, 16 were along the San Diego river, 3 
on the San Rodrigo, and 2 on the Escondido river (Fig. 1). At each site we established a circular plot with an area of $1000 \mathrm{~m}^{2}$, within which individuals of tree species were tallied and their normal diameter (or diameter at breast height, DBH) were measured; individual tree heights were also recorded. For assessing dominant trees species regeneration (individuals $\leq 1.30 \mathrm{~m}$ tall) and characteristics of the herb and shrub stratum, we established $52-\mathrm{m}^{2}$ plots, 1 at the center and 4 near the border of each circular plot, in the corresponding cardinal direction (Olvera-Vargas et al., 1996; Figueroa-Rangel and Olvera-Vargas, 2000). Taxonomic identities of the collected plant specimens were determined and the vouchers deposited at the ANSM herbarium (Universidad Autónoma Agraria Antonio Narro). Vegetation types were defined following Muller (1945) and Villarreal-Quintanilla and Valdés-Reyna (199293), and the structure of their tree stratum was analyzed by calculating the basal area and density of those species representing the adult tree community $(\mathrm{DBH} \geq 5 \mathrm{~cm}$ ). Density, frequency, and absolute dominance values were calculated by species; by adding the relative values of these variables we obtained a Relative Importance Value (RIV) for each species (Mueller-Dombois and Ellenberg, 1974); the abundance-dominance of species in the herb and shrub strata was assessed qualitatively (see Appendix 1). Site classification was performed by applying Ward's method or Minimum Variance method, which is a hierarchical, polythetic, agglomerative clustering technique (Manly, 1986; Digby and Kempton, 1987), using NTSYSpc ver. 2.0 (Rohlf, 1998) to a species/sites matrix containing density values of 13 tree species; between-cluster distance was computed as an increment in squared Morisita's index (Krebs, 1999) towards cluster centroid after fusion of 2 clusters (van Tongeren 1995). Floristic similarity between the 2 communities was assessed by calculating Jaccard's index (Magurran, 1988):

$$
C j=j /(a+b-j)
$$

where $a$ and $b$ represent species richness in each of the 2 examined sets, and $j$ is the number of shared species.

The criteria established in the Regulatory Appendix I (Method for Assessing the Extinction Risk of Wild Species) of the Mexican Official Norm NOM-059SEMARNAT-2001 (Semarnat, 2002) were applied in order to locate 4 species (Quercus fusiformis, Carya illinoinensis, Ulmus crassifolia, and Platanus occidentalis) in the proper risk category; the selection of these species was based on their highly restricted distribution in Mexico. This procedure is based on the sum of the values given to 4 criteria that allow assigning each species to a risk category. These criteria are: (a) size of the taxon's range in Mexico, (b) habitat condition with respect to the natural development of the taxon, (c) intrinsic biological vulnerability of the taxon, and (d) impacts of human activities on the taxon. The maximum sum value for the 4 criteria is 14 points $(4,3,3$, and 4 , respectively). A species is considered in risk of extinction ('peligro de extinción'; $\mathrm{P}$ ) with sum values between 12 and 14 points, and threatened ('amenazada'; A) when they are between 10 and 11 .

\section{Results}

Floristics. A total of 48 species belonging to 29 families were recorded, among which Poaceae, Asteraceae (5 species each), and Malvaceae (4) were prominent. Species distribution by growth form categories was characterized by the dominance of herbs (20 species; $41.66 \%)$ and trees (15 species; 31.25\%), whereas shrubs (6 species, $12.5 \%)$ and climbers (7 species; $14.58 \%$ ) were more poorly represented. Dominant species (and consequently the strongest contributors to physiognomy) in the tree stratum were Carya illinoinensis and Quercus fusiformis; in the subcanopy Celtis reticulata and Diospyros texana were dominant, but Bumelia lanuginosa, Acacia farnesiana, Salix nigra, and Prosopis glandulosa were also noteworthy. The most abundant herbs were Ruellia nudiflora, Sanvitalia ocymoides, Viguiera dentata, Allowissadula holosericea, and Malvastrum coromandelianum. The complete checklist of the flora is presented in Appendix 1.

Site classification. The cluster analysis clearly separated 2 groups of sites (Fig. 2). Group 1 corresponds to oak forest and comprises 19 sites with a mean between-site similarity of $43 \%$; this community encompasses 11 tree species, among which the most common ones were Quercus fusiformis, Celtis reticulata, and Diospyros texana. For this forest we distinguished 3 variants: stands dominated by $Q$. fusiformis (14 sites), others characterized by a co-dominance of $Q$. fusiformis and $C$. reticulata (4), and 1 dominated by species of xeric affinities like Prosopis glandulosa. Group 2 embodies the remaining 11 sites, for which a mean between-site similarity was $23 \%$; they correspond to the walnut forest, which as a whole hosts a tree richness of 10 species, the most frequent ones being Carya illinoinensis, $Q$. fusiformis, and $C$. reticulata. For this community we were also able to distinguish 2 variants, 1 in which dominance corresponds to C. illinoinensis (9 sites), and the other dominated by Ulmus crassifolia (2 sites only). Eight species were shared between the 2 forest types, which produced a Jaccards's similarity index of 0.61 between them. 
Oak forest structure. This community thrives along the San Diego and Escondido rivers, as well as in areas south of Ciudad Acuña, at elevations ranging between 270 and $320 \mathrm{~m}$. Quercus fusiformis (white oak) was the dominant species (RIV of $59.48 \%$; density of 231 stems/ha); the trees of this species form a closed canopy 13 to $25 \mathrm{~m}$ tall. In this forest a second tree stratum was distinguished with trees measuring between 6 and $9 \mathrm{~m}$ tall, in which palo blanco (Celtis reticulata) dominates (RIV of 11.14\%); further common species were Diospyros texana, Carya illinoinensis, and Bumelia lanuginosa (RIVs of 4-10\%). Although Ulmus crassifolia was scarce (3.68 stems/ha), the size of their individuals is noteworthy (mean DBH of $29 \mathrm{~cm}$ ), which led this species to attain a RIV of $1.68 \%$ (Table 1). In sites where canopy was open the occurrence of Prosopis glandulosa (mesquite) and Acacia farnesiana (huizache) trees was observed (RIV of $4.64 \%$ and $1.16 \%$, respectively), along with shrubs such as Opuntia lindheimeri, Leucophyllum frutescens, and Celtis pallida with heights between 1 and $2 \mathrm{~m}$. In the herb stratum, whose height ranges from 10 to $35 \mathrm{~cm}$, Allowissadula holosericea, Croton fruticulosus, Pavonia lasiopetala, and Siphonoglossa pilosella were dominant. Smilax bona-nox and Vitis cinerea were frequent climbers.

In this forest we recorded a total density of 386 stems/ ha in the tree stratum, with tree heights ranging between 6 and $25 \mathrm{~m}$, and mean DBH as large as $44.17 \mathrm{~cm}$, which accounts for its total basal area of $24.36 \mathrm{~m}^{2} / \mathrm{ha}$. A large fraction $\left(21.90 \mathrm{~m}^{2} / \mathrm{ha} ; 89 \%\right)$ of this value was contributed exclusively by Quercus fusiformis, whereas all associated trees combined (10 species) accumulated a basal area $<2$ $\mathrm{m}^{2} /$ ha (Table 1). We did not record any juveniles, so that sprouting was the only regeneration form observed.

The community-level diameter frequency distribution in this forest showed an inverted J shape (Fig. 3). Two thirds of all trees (255 stems, 66\%) had DBH values between 5 and $15 \mathrm{~cm}$; this fraction was accounted for mainly by Diospyros texana, Celtis reticulata, and Carya illinoinensis. The former species had its highest density ( 40 stems/ha) in the $5 \mathrm{~cm}$ centered diameter class, whilst the latter 2 were more abundant in the class centered on the 10 $\mathrm{cm}$ mark (16 and 6 stems/ha, respectively). The large DBH categories were dominated by Quercus fusiformis, whose diameter frequency distribution had a sigmoid shape, with its highest density (41 stems/ha) in the class centered on $15 \mathrm{~cm}$ (Fig. 3).

Walnut forest structure. The Carya illinoinensis community thrives on the banks of the San Diego, San Rodrigo and Arroyo de las Vacas rivers, at elevations ranging from 250 to $300 \mathrm{~m}$. This species was physiognomically and structurally dominant (RIV of $57.58 \%$; density of 230 stems/ha), followed by white oak (Quercus fusiformis) with 13 stems/ha and a RIV of $13.39 \%$. Together, these 2 species make up the upper stratum, which is 12 to $18 \mathrm{~m}$ tall (Table 2). In the lower tree stratum (6 to $8 \mathrm{~m}$ tall) Celtis reticulata, Platanus occidentalis, and Morus celtidifolia were common (RIV of 4-9\%); M. celtidifolia and $P$. occidentalis were only recorded along the San Rodrigo river, both with low densities (16 and 8 stems/ ha, respectively). Ulmus crassifolia occurred exclusively in those open-canopy $C$. illinoinensis communities located near Ciudad Acuña, with a low density ( 5 stems/ha) but a rather robust growth, illustrated by a mean diameter of $47.25 \mathrm{~cm}$ (allowing this species to reach a RIV of $4.06 \%$ ). Bumelia lanuginosa, B. celastrina, and Diospyros texana were uncommon, only recorded in habitats with less water availability. In areas with low forest cover, seedlings and juveniles of Acacia farnesiana and Prosopis glandulosa were frequent, together with xerophytic shrubs like Opuntia lindheimeri and Celtis pallida. Climbers like Vitis cinerea, Smilax bona-nox, and Toxicodendron radicans were common. Plant height in the herb stratum ranged between 5 and $60 \mathrm{~cm}$; in this stratum the most abundant species were Viguiera dentata, Sanvitalia ocymoides, Carex schiedeana, and Abutilon incanum.

Total density in the tree stratum of this community was 302 stems/ha. Tree height ranged between 6 and 18 $\mathrm{m}$, and maximum DBH mean was $64.96 \mathrm{~cm}$. Total basal area was $21.27 \mathrm{~m}^{2} / \mathrm{ha}$, of which over $89 \%\left(18.92 \mathrm{~m}^{2} / \mathrm{ha}\right)$ was accounted for by Carya illinoinensis and Quercus fusiformis (63\% and $26 \%$, respectively). Basal area values of the remaining 8 species were $<1 \mathrm{~m}^{2} /$ ha (Table 2). Seedlings and juveniles of $C$. illinoinensis were scarce and apparently restricted to the most humid sites.

As was the case for the oak forest, diameter frequency distributions of the various species of this forest also exhibited inverted J shapes (Fig. 4). More than one half of all trees (178 individuals; 58\%) had DBH values between 5 and $15 \mathrm{~cm}$. The largest density in these categories was contributed by Carya illinoinensis, whose population diameter distribution matched that observed for the whole community. The large DBH categories exclusively contained C. illinoinensis and Quercus fusiformis individuals; in fact, for the latter species we recorded the largest diameter $(150 \mathrm{~cm})$ in the entire sampling. The most important species in the lower tree stratum were Platanus occidentalis and Celtis reticulata, whose highest densities fell in those categories centered on the 15 and $5 \mathrm{~cm}$ marks, respectively (Fig. 4).

Proposal for the protection of tree species. By applying the criteria of the Regulatory Appendix I of the Mexican Norm NOM-059-SEMARNAT-2001, we propose that Quercus fusiformis, Carya illinoinensis and Ulmus crassifolia be classified as 'In danger of local extinction', 
Table 1. Structural attributes of the tree stratum in the oak (Quercus fusiformis) forest in the Northeastern Coastal Plain, Coahuila, Mexico. RIV = Relative Importance Value

\begin{tabular}{|c|c|c|c|c|c|c|c|}
\hline Species & $\begin{array}{c}\text { Mean } D B H \\
(\mathrm{~cm})\end{array}$ & $\begin{array}{l}\text { Density } \\
\text { (ind/ha) }\end{array}$ & $\begin{array}{c}\text { Relative } \\
\text { density (\%) }\end{array}$ & $\begin{array}{c}\text { Basal area } \\
\left(m^{2} / h a\right)\end{array}$ & $\begin{array}{c}\text { Relative } \\
\text { dominance } \\
(\%)\end{array}$ & $\begin{array}{c}\text { Relative } \\
\text { frequency } \\
(\%)\end{array}$ & $R I V$ \\
\hline Quercus fusiformis & 44.17 & 231.05 & 59.73 & 21.91 & 89.93 & 28.79 & 59.48 \\
\hline Celtis reticulata & 16.43 & 42.11 & 10.88 & 0.70 & 2.86 & 19.70 & 11.15 \\
\hline Diospyros texana & 7.86 & 58.42 & 15.10 & 0.31 & 1.26 & 12.12 & 9.49 \\
\hline Carya illinoinensis & 23.09 & 19.47 & 5.03 & 0.88 & 3.61 & 12.12 & 6.92 \\
\hline Prosopis glandulosa & 12.96 & 15.79 & 4.08 & 0.18 & 0.75 & 9.09 & 4.64 \\
\hline Bumelia lanuginosa & 9.13 & 12.63 & 3.27 & 0.09 & 0.37 & 6.06 & 3.23 \\
\hline Ulmus crassifolia & 29.79 & 3.68 & 0.95 & 0.26 & 1.08 & 3.03 & 1.69 \\
\hline Acacia farnesiana & 11.25 & 1.58 & 0.41 & 0.01 & 0.06 & 3.03 & 1.17 \\
\hline Condalia hookeri & 12.00 & 1.05 & 0.27 & 0.01 & 0.05 & 3.03 & 1.12 \\
\hline Morus celtidifolia & 15.00 & 0.53 & 0.14 & 0.009 & 0.04 & 1.52 & 0.56 \\
\hline Bumelia celastrina & 6.00 & 0.53 & 0.14 & 0.001 & 0.006 & 1.52 & 0.55 \\
\hline Total & & 386.84 & 100.00 & 24.36 & 100.00 & 100.00 & 100.00 \\
\hline
\end{tabular}

Table 2. Structural attributes of the tree stratum in the walnut (Carya illinoinensis) forest in the Northeastern Coastal Plain, Coahuila, Mexico. RIV = Relative Importance Value

\begin{tabular}{|c|c|c|c|c|c|c|c|}
\hline Species & $\begin{array}{c}\text { Mean } D B H \\
\text { (cm) }\end{array}$ & $\begin{array}{l}\text { Density } \\
\text { (ind/ha) }\end{array}$ & $\begin{array}{c}\text { Relative } \\
\text { density (\%) }\end{array}$ & $\begin{array}{c}\text { Basal area } \\
\left(m^{2} / h a\right)\end{array}$ & $\begin{array}{c}\text { Relative } \\
\text { dominance } \\
(\%)\end{array}$ & $\begin{array}{c}\text { Relative } \\
\text { frequency } \\
(\%)\end{array}$ & $R I V$ \\
\hline Carya illinoinensis & 36.13 & 230.75 & 76.24 & 13.40 & 63.02 & 32.26 & 57.58 \\
\hline Quercus fusiformis & 64.96 & 13.58 & 4.49 & 5.53 & 25.99 & 9.68 & 13.39 \\
\hline Celtis reticulata & 27.45 & 11.28 & 3.73 & 0.51 & 2.40 & 19.36 & 8.57 \\
\hline Platanus occidentalis & 16.97 & 16.44 & 5.43 & 0.55 & 2.57 & 6.45 & 4.79 \\
\hline Morus celtidifolia & 16.29 & 8.12 & 2.68 & 0.20 & 0.96 & 9.68 & 4.48 \\
\hline Ulmus crassifolia & 47.13 & 5.87 & 1.94 & 0.92 & 4.33 & 6.45 & 4.06 \\
\hline Bumelia lanuginosa & 7.41 & 11.65 & 3.85 & 0.09 & 0.42 & 6.45 & 3.51 \\
\hline Salix nigra & 30.00 & 1.53 & 0.51 & 0.06 & 0.28 & 3.23 & 1.26 \\
\hline Bumelia celastrina & 8.00 & 1.47 & 0.49 & 0.004 & 0.02 & 3.23 & 1.18 \\
\hline Diospyros texana & 8.00 & 1.99 & 0.66 & 0.004 & 0.02 & 3.23 & 1.18 \\
\hline Total & & 302.67 & 100.00 & 21.27 & 100.00 & 100.00 & 100.00 \\
\hline
\end{tabular}



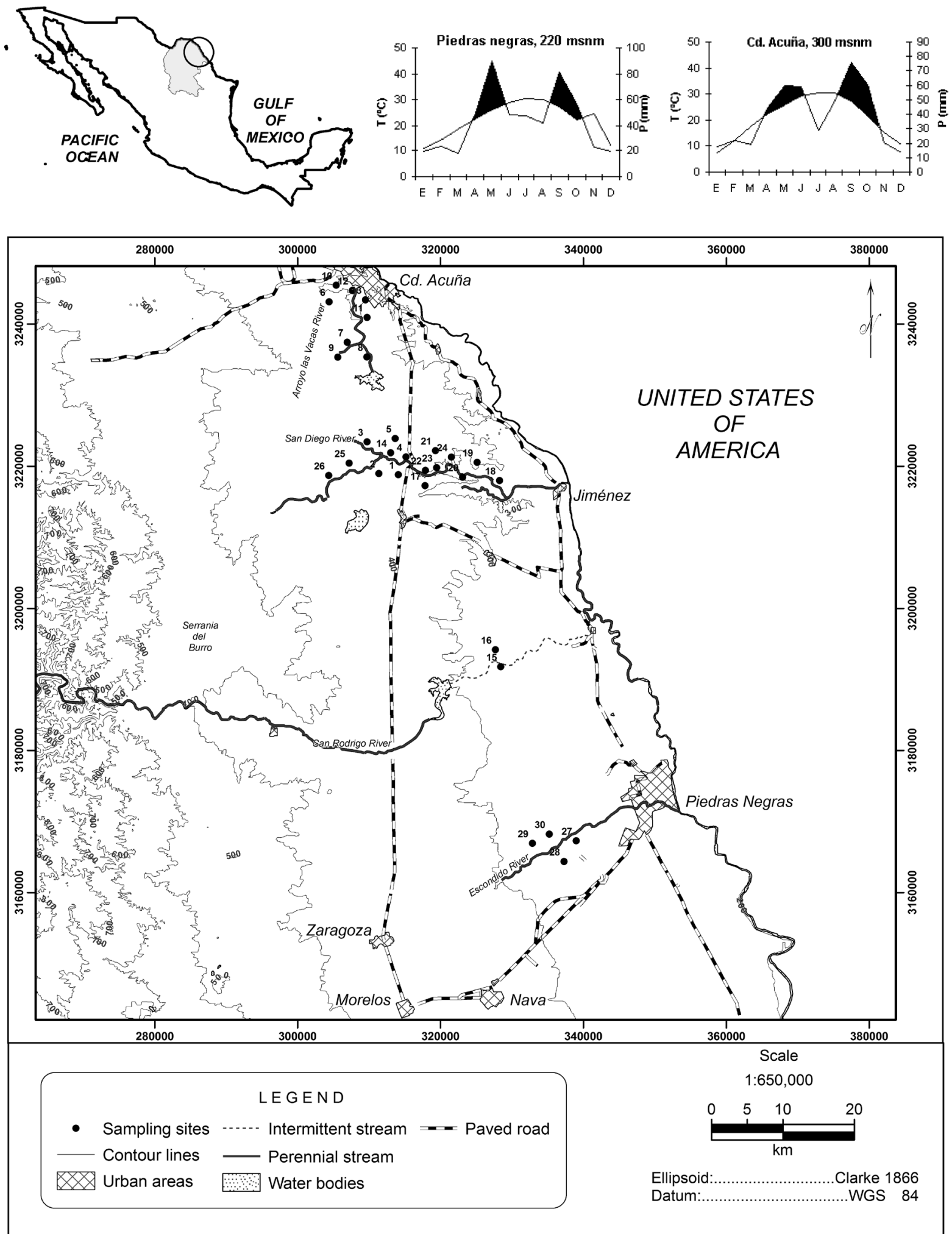

Figure 1. Location of the study area and the sampling sites in the Northeastern Coastal Plain, Mexico (UTM 14N). 


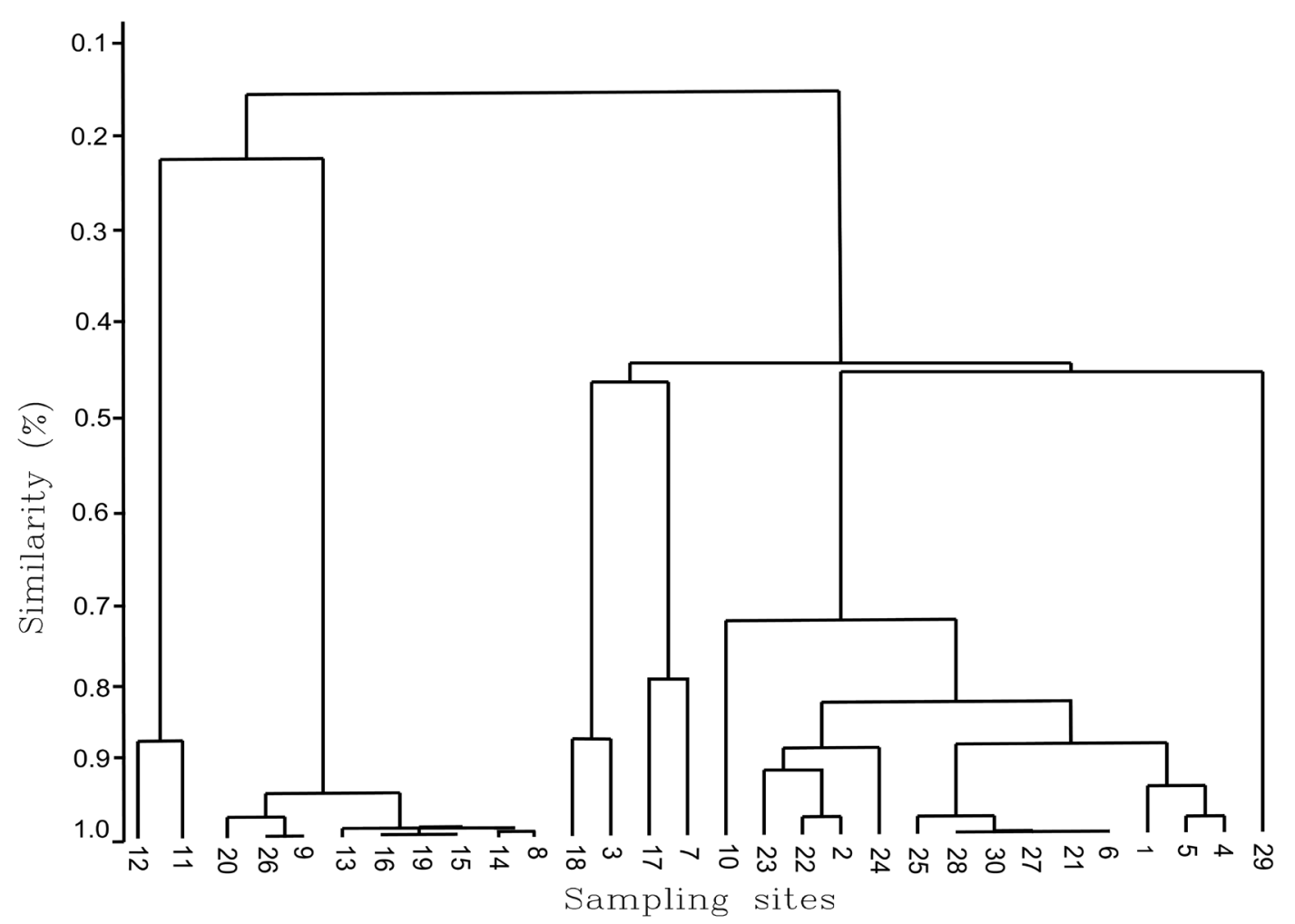

Figure 2. Site classification based on Ward's (Minimum Variance) method for the Quercus fusiformis and Carya illinoinensis forests.

whereas Platanus occidentalis corresponds better to the 'Threatened' category'. These standings were based on the criterion of the restricted ranges of these species to Mexico and to Coahuila State.

\section{Discussion}

Forests dominated by Quercus and Carya species of northeastern Mexico are essentially restricted to humid ravines of mountainous regions, in temperate areas with elevations ranging from 900 to $2600 \mathrm{~m}$, and shallow soils (Briones, 1991; Muller-Using, 1994; Eckelmann, 1995; Encina-Domínguez, 2003). The Quercus fusiformis and Carya illinoinensis forests typical of the Coastal Plain of Coahuila greatly contrast with them due to their occurrence at much lower elevations $(250-350 \mathrm{~m})$, their strong preference for humid locations near streams, and their occurrence in temperate and semiarid habitats with deeper soils. Moreover, these forests may represent relict communities (Rzedowski, 1978), and indeed they can be viewed as an outstanding plant community, as it is the only one in the country that is composed of species with clear temperate climate affinities that occurs within a semiarid environment. In southeastern USA Carya illinoinensis dominated forests are common (Bonner and Maisenhelder, 1974; Peterson, 1990; Fowler, 2005), but the southernmost limit of this community's range is found in our study region; further south this tree species only occurs as an isolated component of riparian vegetation and oak forests of central Coahuila (Villarreal-Quintanilla et al., 2006), south central Nuevo León (Muller-Using, 1994; Treviño et al., 2001), and central Mexico (Pérez-Calix, 2001).

Floristic composition and phytogeographical affinities. Total species richness recorded in the oak and walnut forests of Coahuila is lower than that reported by VillarrealQuintanilla et al. (2006) for the Sabinas and San Rodrigo rivers (243 taxa), and the same was true for tree species richness ( 22 species versus 15 recorded by us). In spite of these differences, both studies coincide in pointing out the prevalence of the Asteraceae and Poaceae families. Tree richness in forests of the Eastern Sierra Madre fluctuates between 3 and 6 species (Briones, 1991; Muller-Using, 1994; Encina-Domínguez, 2003), which is less than our records for the Quercus fusiformis (11 species) and the walnut (10 species) forests, and less than figures reported 

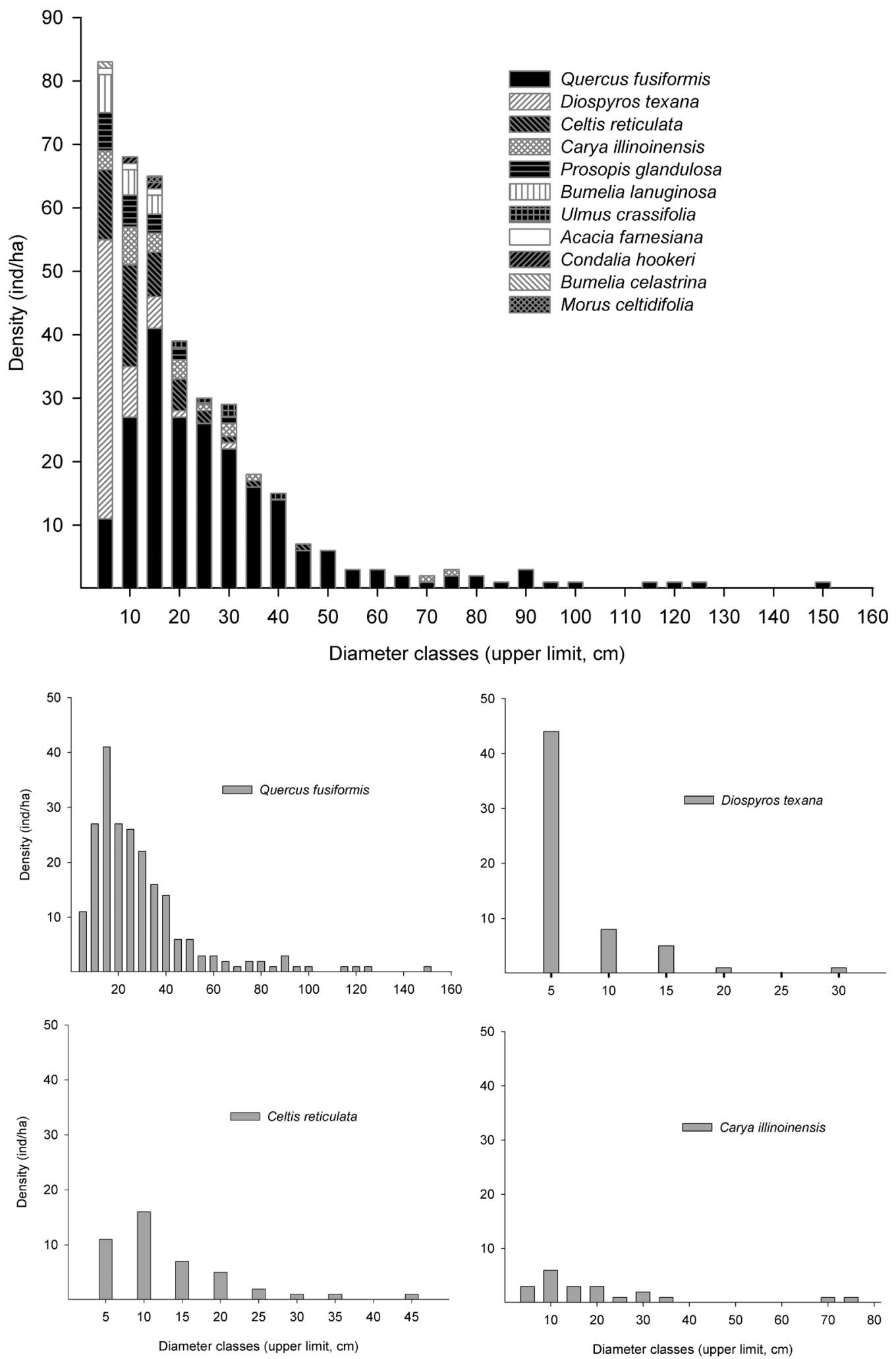

Figure 3. Diameter structure of the Quercus fusiformis forest and dominant species. 

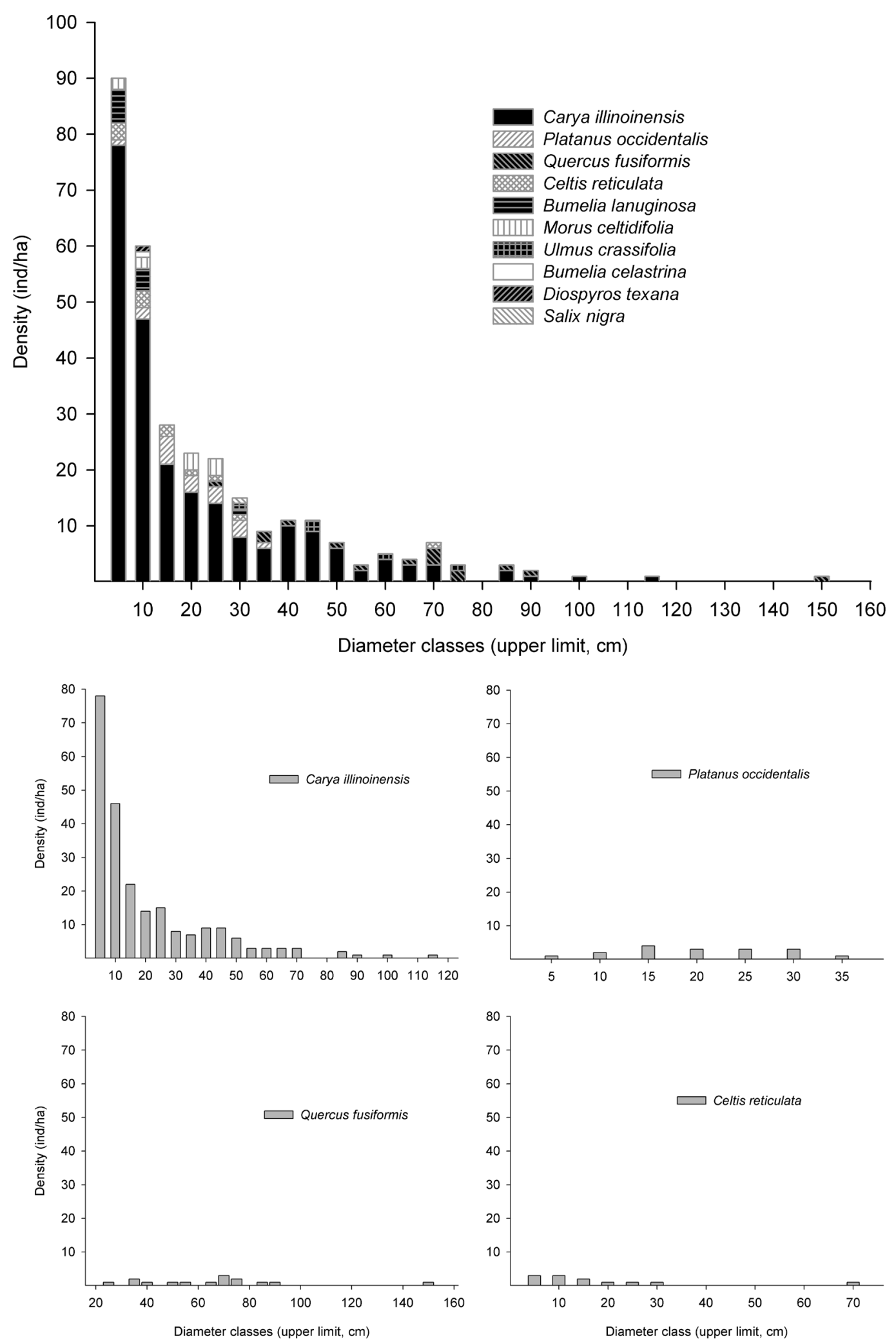

Figure 4. Diameter structure of the Carya illinoinensis forest and dominant species. 
for gallery forests of the Ramos and Cabezones rivers in Nuevo León, where Treviño et al. (2001) tallied 16 and 21 species, respectively.

In the forests studied by us, the tree stratum is dominated by genera of Nearctic affinity (Rzedowski et al., 2001), and only at sites with a more open canopy is there presence of Neotropical trees, such as members of Acacia and Prosopis. Conversely, in the herb and shrub strata Neotropical elements often dominate (Rzedowski, 1965). The fact that Asteraceae and Poaceae are the most speciose families in the herb stratum of the oak forest agrees with observations from other Mexican oak forests (Rzedowski, 1978); however, as in broadleaved forests of central Texas, malvaceous species dominate such strata (Fowler, 2005).

The high similarity between sites representing the oak and walnut forests demonstrates their large share of common species, probably due to similar ecological requirements among their floristic sets (Johnston, 1944; VillarrealQuintanilla et al., 2006). Also, it leads to the conclusion that these 2 forests represent a single community with 2 variants, differentiated by the respective strong dominance of Carya illinoinensis and Quercus fusiformis, whilst the variation in their composition and the discontinuity in their distribution is largely an outcome of the anthropogenic activity in the region.

Ecological factors affecting vegetation. The segregation of sampling sites in 2 variants of a single oak-walnut forest is not only due to subtle differences in floristic composition and to the higher densities of some species in either variant, but it is also related to overall ecological differences between them. The variant recognized by us as walnut forest is preferentially found on river banks, at higher altitudes and more northern latitudes, and its range includes a clear temperature gradient, whereas the geographical range of oak forest stretches more to the south where temperatures are higher; this latter forest can develop near or far away from rivers, as long as there is a shallow water table (Rzedowski, 1978), and it often forms isolated clusters, locally known as motas, scattered across the Tamaulipan thorn scrub. Zavala (2001) reported similar ecological properties for other Quercus species and emphasized that oaks are droughttolerant, whilst they cannot withstand flooding and excess soil moisture. Forest composition and distribution are largely determined by temperature and humidity; the distributions of Carya illinoinensis, Morus celtidifolia, Platanus occidentalis, and Ulmus crassifolia, all of them typical walnut forest species, are limited to the most humid sites within the area. Conversely, the remaining species appear to be more tolerant to variable temperate and water conditions, as they were recorded in most sampling sites.
Forest structure and regeneration. Oak forests of northeastern Mexico are usually dominated by 2 or 3 tree species reaching heights of 8 to $10 \mathrm{~m}$, with diameters of 19 to $22 \mathrm{~cm}$ and densities between 220 and 240 stems/ha (Briones, 1991; Muller-Using, 1994; Baca, 2000; Torres, 2000; Encina-Domínguez, 2003). These forests differ from the communities studied by us because of the clear single-species dominance in the latter, whose individuals generally grow to larger sizes (DBH and mean height of $44.17 \mathrm{~cm}$ and $15 \mathrm{~m}$, respectively), despite similar values of mean density. The likely cause for the larger sizes of trees (and forests) in the Coastal Plain of Coahuila is a higher productivity derived from a higher nutrient and moisture availability compared to environmental conditions in mountainous regions; this possibility would also strengthen the argument for the suggested mature and relict condition of these forests.

Basal areas estimated by us were slightly higher in the oak than in the walnut forest. This finding may be related to a combination of a higher stem density with larger stem diameters of Quercus fusiformis in this forest, relative to the same variables measured for Carya illinoinensis in the walnut forest variant.

The diameter class distributions of both communities had inverted J shapes, which in principle could be interpreted as a sign of good forest regeneration (Kormondy, 1985). Nonetheless, only the densities of 2 out of the 5 most important species peaked in the $5 \mathrm{~cm}$ DBH class, namely Carya illinoinensis and Diospyros texana, whereas the remaining ones were poorly represented in that category, suggesting an insufficient or poor regeneration (Bongers et al., 1988; Godínez-Ibarra and López-Mata, 2002; Ajbilou et al., 2003; Ayerde-Lozada and López-Mata, 2006). In many oak populations facing difficulties to regeneration from seeds, a situation resulting not only from human intervention but also from a combination of many factors such as herbivory, exotic grass invasions, and summer drought (MacDougall et al. 2010), sprouting becomes the only regeneration alternative (Zavala and García, 1997; Johnson et al., 2002). However, sprouting does not necessarily guarantee a healthy regeneration, as shown by significant grazing on sprouts by goats and white-tail deer in Quercus fusiformis central Texas populations (Fowler 2005).

Anthropogenic disturbance. Anthropogenic impact is a further factor capable of exerting a considerable influence on community structure and composition. Human influence on the studied forests is manifold: grazing of cattle, sheep, and horses; selective logging of oaks and other species; land used change to establish agricultural areas; diversion of rivers; construction of reservoirs and the mining of river banks (Arriaga et al., 2000; Anonymous, 2001). Its 
action has resulted in the fragmentation and reduction of the range of these oak-walnut forests and the promotion of significant modifications in their structure and species composition, similar to changes reported for temperate and riparian forests of western USA (Norton, 1996; Dwire and Kauffman, 2003). In Coahuila, human activities include the cutting of young trees (mostly of Quercus fusiformis and Celtis reticulata) for fence construction and charcoal production, and overgrazing (unpub. obs.); interestingly, these were also recognized by Ajbilou et al. (2003) as the main reasons for the poor regeneration of Quercus forests in Marocco. Overall, Q. fusiformis and Carya illinoinensis seedlings are scarce and concentrate under the canopies of seeding trees, a pattern also shown by Quercus rugosa along a disturbance gradient that includes varying levels of canopy openness (Bonfil and Soberón, 1999). Our data suggest a higher impact on the regeneration of oak than of walnut forest; moreover, there seems to be an intrinsic reason for the overgrazing of this forest variant, since recently flushed oak leaves are more palatable than those of walnut (Andersson, 1991) and therefore grazed more intensely. In oak forests of Nuevo León (Mexico), cattle grazing concentrated on $67 \%$ of Quercus cupreata and $Q$. prinopsis resprouted stems, whereas Carya myristicaeformis seedlings were the least affected by cattle (Eckelmann, 1995). Moreover, in the Coahuilan forests $C$. illinoinensis displays a better seed reproduction than oaks (pers. obs.).

Human-induced changes in canopy structure are related to diversity losses and species invasions (Hobbs and Huenneke, 1992). In our study area, sites with low canopy cover appear to be gradually colonized by species from the neighboring thorn scrub, with Prosopis glandulosa and Acacia farnesiana acting as disturbance indicator species (Sttubbendieck et al., 1992). Prosopis glandulosa was recorded by us in almost one fifth of all oak forest sites, where past tree extraction was evident. Such changes warrant the suspicion that regional xerophytic communities are increasingly replacing these forests. An analogous deteriorating process was observed in the mountains of Chiapas, southern Mexico, where humandisturbed oak forests are being gradually replaced by pine-dominated stands (González-Espinosa et al., 1995a, b). In southeastern USA, reservoir construction and mining in open-air quarries have triggered the transformation of riparian forests into scrub vegetation (Busch and Smith, 1995; Everitt, 1998; Shafroth et al., 2002).

The negative effects of human activities are not exclusively seen in the upper canopy, as our results provide evidence of species richness reductions in the lower tree stratum: sites showing stronger human impact consistently had fewer species in this stratum, and in extreme cases mature oaks and walnut trees were the only plants occurring at the site. Human-caused floristic richness reductions have also been documented for cloud forests of Chiapas (Ramírez-Marcial et al., 2001). If current management practices were to continue, these communities are highly likely to disappear in the long run.

Implications for oak and walnut forests protection. The region where we conducted this study hosts a relatively large biodiversity; consequently, it was included in the Priority Terrestrial Regions for Conservation Nos. 73 and 74 defined by the Mexican Government, named Sierra El Burro-Rio San Rodrigo, and Cinco Manantiales, respectively (Arriaga et al., 2000). Worldwide, the area devoted to temperate forest protection is notably scant (Norton, 1996). Protection of these Coahuilan forests started in June 18, 1940, with the publication of the official ordinance that created the Los Novillos National Park (Gómez-Pompa et al., 1995), a 42-ha nature protection area located along the Arroyo de las Vacas river, $65 \mathrm{~km}$ southeast of Ciudad Acuña (Anonymous, 1993). Obviously, this small area cannot guarantee the conservation of these forests, considering the minute representation of their total area $(0.09 \%)$, the regeneration problems faced by most species, and the numerous factors threatening their permanence. Therefore, the protection of oak and walnut forests of the Northeastern Coastal Plain must be decidedly promoted, as in the entire territory of Mexico this is the only region where they occur and, even there, they only cover $1.84 \%$ of Coahuila State (Anonymous, 2001). Further criteria supporting the need to conserve these forests are their insular condition within a semiarid ecosystem dominated by the Tamaulipan Thorn Scrub (Villarreal-Quintanilla and Valdés-Reyna, 1992-93), and the consideration of at least one of the variants (i.e., the Quercus fusiformis forest) as a relict of formerly more extensive forests (Rzedowski, 1978). Ultimately, conservation of these uncommon and particular Coahuilan forests will rely on an adequate management through rational forest exploitation, as well as on an active research program aimed at understanding the dynamics of their dominant species.

\section{Acknowledgments}

We thank 2 anonymous reviewers for their critical comments on an earlier version of this paper. We are grateful to the ANSM herbarium for the support provided to this research. José A. Villarreal kindly determined herb species collected during the project, and Miguel A. Carranza made available to us his collecting logbook for the study area. We thank Felipe N. Hernández for drawing figures 1 and 2 . 


\section{Literature cited}

Ajbilou, R., T. Marañón and J. Arroyo. 2003. Distribución de clases diamétricas y conservación de bosques en el norte de Marruecos. Investigación Agraria, Sistemas de Recursos Forestales 12:111-123.

Alanís, G., G. Cano and M. Rovalo. 1996. Vegetación y Flora de Nuevo León: una Guía Botánico-Ecológica. Impresora Monterrey, Monterrey, N.L. 120 p.

Andersson, C. 1991. Distribution of seedlings and saplings of Quercus robur in a grazed deciduous forest. Journal of Vegetation Science 2:279-282.

Anonymous. 1983. Síntesis Geográfica de Coahuila. Instituto Nacional de Estadística Geografía e Informática. Secretaría de Programación y Presupuesto. Mexico City, D.F. 163 p.

Anonymous. 1993. Áreas Naturales Protegidas de México. Secretaría de Desarrollo Social, Mexico City, D.F. 216 p.

Anonymous. 2001. Ordenamiento Ecológico de Coahuila, México. Instituto Coahuilense de Ecología, Gobierno de Coahuila, Saltillo. 1072 p.

Arriaga, L., J. M. Espinoza, C. Aguilar, E. Martínez, L. Gómez and E. Loa (coords.). 2000. Regiones Terrestres Prioritarias de México. Comisión Nacional para el Conocimiento y Uso de la Biodiversidad, Mexico, D.F. 609 p.

Ayerde-Lozada, D. and L. López-Mata. 2006. Estructura poblacional y parámetros demográficos de Juniperus flaccida Schltdl. Madera y Bosques 12:65-76.

Baca, J. 2000. Caracterización de la estructura vertical y horizontal en bosques de pino-encino. M.Sc. Thesis, Facultad de Ciencias Forestales, Universidad Autónoma de Nuevo León, Linares. 93 p.

Bonner, F. T. and L. C. Maisenhelder. 1974. Carya Nutt. Hickory. In Seeds of Woody Plants in the United States, C.S. Schopmeyer (coord.). Agricultural Handbook, United States Department of Agriculture, Forest Service, Washington, D.C. $450 \mathrm{p}$.

Bonfil, C. and J. Soberón. 1999. Quercus rugosa seedling dynamics in relation to its re-introduction in a disturbed Mexican landscape. Applied Vegetation Science 2:189-200.

Bongers, F., J. Popma, J. Meave del Castillo and J. Carabias. 1988. Structure and floristic composition of the lowland rain forest of Los Tuxtlas, Mexico. Vegetatio 74:55-80.

Briones, O. 1991. Sobre la vegetación y fitogeografía de la Sierra de San Carlos, Tamaulipas. Acta Botanica Mexicana 16:15-44.

Busch, D. E. and S. D. Smith. 1995. Mechanisms associated with decline of woody species in riparian ecosystems of the southwestern US. Ecological Monographs 65:347-370.

Correll, D. S. and M. C. Johnston. 1970. The Manual of the Vascular Plants of Texas. Texas Research Found. Renner, Texas. $1881 \mathrm{p}$.

Digby, P. G. and R. A. Kempton. 1987. Multivariate Analysis of Ecological Communities. Chapman \& Hall, London. 206 p.
Dwire, K. A. and J. Kauffman. 2003. Fire and riparian ecosystems in landscapes of the western USA. Forest Ecology and Management 178:61-74.

Eckelman, C. M. 1995. Regeneración y dinámica sucesional de un bosque de pino-encino en la Sierra Madre Oriental en el Noreste de México. Memorias del III Seminario Nacional sobre utilización de encinos. Reporte Científico UANL, No. Especial 15. Universidad Autónoma de Nuevo León, Linares. p. 199-212.

Encina-Domínguez, J. 2003. Aspectos estructurales, caracterización ecológica y diversidad de los bosques de encino de la Sierra de Zapalinamé, Coahuila, México. M.Sc. Thesis, Universidad Autónoma Agraria Antonio Narro, Saltillo. 173 p.

Encina-Domínguez, J. and J. A. Villarreal-Quintanilla. 2002. Distribución y aspectos ecológicos del género Quercus L. en el estado de Coahuila, México. Polibotánica 13:1-23.

Everitt, B. L. 1998. Chronology of the spread of tamarisk in the central Rio Grande. Wetlands 18:283-296.

Ferrusquía-Villafranca, I. 1993. Geology of Mexico: a synopsis. In Biological Diversity of Mexico; Origins and Distribution, T.P. Ramamoorthy, R. Bye, A. Lot, J. Fa (eds.). Oxford University Press, New York. p. 3-107.

Figueroa-Rangel, B. L. and M. Olvera-Vargas. 2000. Dinámica de la composición de especies en bosques de Quercus crassipes H. \& B. en Cerro Grande, sierra de Manantlán, México. Agrociencia 34:91-98.

Fowler, N. L. 1988. Grasslands, nurse trees, and coexistence. In Edwards Plateau Vegetation: Plant Ecological Studies in Central Texas, B.B. Amos and F.R. Gelbach (eds.). Baylor University Press, Waco. p. 91-100.

Fowler, N. L. 2005. An introduction to the vegetation and ecology of the eastern Edwards Plateau (Hill Country) of Texas. http:77www.sbs.utexas.edu/fowler/index.htm; 15.III-2010.

Godínez-Ibarra, O. and L. López-Mata. 2002. Estructura, composición, riqueza y diversidad de árboles de tres muestras de selva mediana subperennifolia. Anales del Instituto de Biología de la Universidad Nacional Autónoma de México, Serie Botánica 73:283-314.

Gómez-Pompa, A., R. Dirzo, B. H. Fernández and E. G. Becerra, 1995. Las Reservas de la Biosfera y otras Áreas Naturales Protegidas de México. SEMARNAP. INE. CONABIO. 160 p.

González-Medrano, F. 1985. El límite sur de la Provincia Biótica Tamaulipeca. Resúmenes del II Simposio Internacional sobre la Provincia Biótica Tamaulipeca, 6-8 marzo 1985. Universidad Autónoma de Tamaulipas y Universidad Nacional Autónoma de México. Ciudad Victoria, Tamps.

González-Espinosa, M., S. Ochoa-Gaona, N. Ramírez-Marcial and P. F. Quintana-Ascencio. 1995a. Current land-use trends and conservation of old-growth forest habitats in the highlands of Chiapas, Mexico. In Conservation of 
Neotropical Migratory Birds in Mexico. M.M. Wilson and S.S Sader (eds.). Maine Agricultural and Forest Experiment Station, Orono. p. 190-198.

González-Espinosa, M., N. Ramírez-Marcial, P. F. QuintanaAscencio and M. Martínez. 1995b. La utilización de encinos y la conservación de la biodiversidad en Los Altos de Chiapas. Memorias del III Seminario Nacional sobre Utilización de Encinos. Reporte Científico UANL, No. Especial 15, Universidad Autónoma de Nuevo León, Linares. p. 183-197.

Hobbs, R. J. and L. F. Hienneke. 1992. Disturbance, diversity, and invasion: implications for conservation. Conservation Biology 6:324-337.

Johnson, P. M., S. R. Shifley and R. Rogers. 2002. The Ecology and Silviculture of Oaks. CABI Publishing, Oxon. 544 p.

Johnston, I. M. 1944. Plants of Coahuila, eastern Chihuahua, and adjoining Zacatecas and Durango, IV. Journal of the Arnold Arboretum 25:431-453.

Kormondy, E. J. 1985. Conceptos de Ecología. Alianza Universitaria. Madrid. 275 p.

Krebs, C. J. 1999. Ecological Methodology. Addison Wesley Logman, New York. 618 p.

Lot, A. and A. Novelo. 1990. Forested wetlands of Mexico. In Forested Wetlands of the World, Vol. 15, A.M. Lugo, M.M. Brison and S. Brown (eds.). Ecosystems of the World, Elsevier, Amsterdam. p. 287-298.

MacDougall, A., A. Duwyn and N. T. Jones. 2010. Consumerbased limitation drive oak recruitment failure. Ecology 91:2092-2099.

Magurran, A. E. 1988. Ecological Diversity and its Measurement. Princeton University Press. Princeton, New Jersey. 179 p.

Manly, B. F. 1986. Multivariate Methods. Chapman \& Hall, London. 159 p.

Marroquín, R. A. 1985. El género Quercus L. al noroeste del estado de Nuevo León. Bachelor's Thesis, Facultad de Ciencias Biológicas, Universidad Autónoma de Nuevo León, Monterrey. $56 \mathrm{p}$.

Muller, C. H. 1945. Vegetation and climate of Coahuila. Madroño 9:33-57.

Muller, C. H. 1951. The oaks of Texas. Contributions from the Texas Research Foundation 1:21-313.

Muller-Using B. 1994. Contribuciones al conocimiento de los bosques de encino y pino-encino en el Noreste de México. Reporte Científico No. Especial 14. Facultad de Ciencias Forestales, Universidad Autónoma de Nuevo León, Linares. $181 \mathrm{p}$.

Mueller-Dombois D. and H. Ellenberg. 1974. Aims and Methods of Vegetation Ecology. John Wiley \& Sons, New York. 547 p.

Norton, T. W. 1996. Conservation of biological diversity in temperate and boreal forest ecosystems. Forest Ecology and Management 85:1-7.

Olvera-Vargas., S. Moreno-Gómez and B. Figueroa-Rangel. 1996. Sitios Permanentes para la Investigación Silvícola.
Manual para su Establecimiento. Libros del Instituto Manantlán. Universidad de Guadalajara, Guadalajara. 55 p.

Patten, D. T. 1998. Riparian ecosystems of semi-arid North America: diversity and human impacts. Wetlands 18:498-512.

Pérez-Calix, E. 2001. Flora del Bajío y regiones adyacentes: Juglandaceae. Fascículo 96. Instituto de Ecología, A.C., Centro Regional del Bajío, Pátzcuaro, Mich. 15 p.

Peterson, J. K. 1990. Carya illinoensis (Wangenth.) K.Koch, Pecan. In Silvics of North America Vol. 2., R. M. Burns and B.H. Honkala (coord.). Hardwoods. Agricultural Handbook, United States Department of Agriculture, Forest Service, Washington, D.C. 654 p.

Ramírez-Marcial, N., M. González-Espinosa and G. WilliamsLinera. 2001. Anthropogenic disturbance and tree diversity in montane rain forest in Chiapas, Mexico. Forest Ecology and Management 154:311-326.

Rohlf, F. J. 1998. NTSYSpc. Numerical Taxonomy and Multivariate Analysis Version 2.0. Applied Biostatistics Inc., New York. 177 p.

Rzedowski, J. 1965. Relaciones geográficas y posibles orígenes de la flora de México. Boletín de la Sociedad Botánica de México 29:121-177.

Rzedowski, J. 1978. Vegetación de México. Editorial Limusa. Mexico City, D.F. 432 p.

Rzedowski, J. and Calderón de Rzedowski G. (eds.). 2001. Flora fanerogámica del Valle de México. 2a. ed., Instituto de Ecología, A.C. y Comisión Nacional para el Conocimiento y Uso de la Biodiversidad, Pátzcuaro, Mich. 1406 p.

SEMARNAT [Secretaría del Medio Ambiente y Recursos Naturales]. 2002. Norma Oficial Mexicana NOM-059SEMARNAT-2001 que determina las especies nativas de México de flora y fauna silvestres - categorías de riesgo y especificaciones para su inclusión, exclusión o cambio - lista de especies en riesgo. Diario Oficial de la Federación, 2a sección, March 6th, 2002.

Shafroth, P. B., J. C. Stromberg and D. T. Patten. 2002. Riparian vegetation response to altered disturbance and stress regimens. Journal of Applied Ecology 12:107-123.

Solís, G. G. and P. Jenkins. 1998. Riparian vegetation on the río Santa Cruz, Sonora. USDA Forest Service Proceedings 5:100-118.

Sttubbendieck, J., S. L. Hatch and C. H. Butterfield. 1992. North American Range Plants. 4th ed., University of Nebraska Press. Lincoln. 493 p.

Torres, E. L. 2000. Análisis estructural de un ecosistema multicohortal de Pinus-Quercus en una fracción de la Sierra Madre Oriental. M.Sc. Thesis, Facultad de Ciencias Forestales, Universidad Autónoma de Nuevo León. Linares. 78 p.

Treviño, G. E., C. Cavazos and O. Aguirre. 2001. Distribución y estructura de los bosques de galería en dos ríos del centro sur de Nuevo León. Madera y Bosques 7:13-25.

Valdés, T. V. and M. L. Aguilar. 1983. El género Quercus en las 
unidades fisonómico-florísticas del municipio de Santiago, N.L. México. INIF-SARH. México. Boletín Técnico No. 98, Secretaría de Agricultura y Recursos Hidráulicos, Mexico City, D.F. 94 p.

van Tongeren, O. F. R. 1995. Cluster analysis, In Data Analysis in Community and Landscape Ecology, R. H. G. Jongman, C. J. F. ter Braak and O. F. R. van Tongeren (eds.). Cambridge University Press, Cambridge. p. 174-212.

Villarreal-Quintanilla, J. A. 2001. Listados florísticos de México. XXIII Flora de Coahuila. Universidad Nacional Autónoma de México, Mexico, D.F. 139 p.

Villarreal-Quintanilla, J. A., M. A. Carranza, E. Estrada and A. Rodríguez. 2006. Flora riparia de los ríos Sabinas y San
Rodrigo, Coahuila, México. Acta Botanica Mexicana 75:1-20. Villarreal-Quintanilla, J. A. and J. Valdés-Reyna. 1992-93. Vegetación de Coahuila, México. Revista de la Sociedad Mexicana de Manejo de Pastizales 6:9-18.

Ward, J. 1963. Hierarchical grouping to optimize an objective function. Journal of the American Statistical Association 58:236-244.

Zavala, F. 2001. Introducción a la Ecología de la Regeneración Natural de Encinos. Universidad Autónoma de Chapingo, Chapingo. 94 p.

Zavala, F. and E. García. 1997. Plántulas y rebrotes en la regeneración de encinos en la Sierra de Pachuca, Hidalgo. Agrociencia 31:323-329.

Appendix 1. Floristic checklist of the oak (Quercus fusiformis) and walnut (Carya illinoinensis) forests of the Northeastern Coastal Plain, Coahuila, Mexico.

Abbreviations of collector names: $\mathrm{C}=$ Miguel Agustín Carranza Pérez, E = Juan A. Encina Domínguez, R=Andrés Rodríguez Gámez, $\mathrm{V}=$ José A. Villarreal Quintanilla. The vouchers were deposited in the ANSM herbarium, Universidad Autónoma Agraria Antonio Narro, Saltillo (Coahuila), Mexico.

\section{Family / Species}

\section{ACANTHACEAE}

Ruellia nudiflora (Engelm. et A.Gray) Urb. var. nudiflora

Ruellia occidentalis (A.Gray) Tarph et F.A.Barkley

Siphonoglossa pilosella (Nees) Torr.

\section{ANACARDIACEAE}

Toxicodendron radicans (L.) Kuntze subsp. eximium (Greene) Gillis

\section{ASTERACEAE}

Baccharis salicifolia (Ruiz et Pav.) Pers.

Calyptocarpus vialis Less

Sanvitalia ocymoides DC

Viguiera dentata (Cav.) Spreng. var. dentata

Xanthium strumarium L.

$\begin{array}{ccc}\text { E 1862 } & \text { Herb } & \text { Abundant } \\ & \text { Herb } & \text { Scarce } \\ ----- & \text { Herb } & \text { Frequent }\end{array}$

E 1069, C 2571, V
6000 $\quad$ Vine $\quad$ Frequent

$\begin{array}{ccc}\text { E 1074, C 2569 } & \text { Shrub } & \text { Scarce } \\ \text { E 1845, C 3372, R } & \text { Herb } & \text { Abundant } \\ 1245 & \text { Herb } & \text { Frequent } \\ ------- & \text { Herb } & \text { Abundant } \\ \text { E 1886, C 3433, R } & \text { Scarce }\end{array}$

CACTACEAE

Opuntia lindheimeri Engelm.

CYPERACEAE

Carex schiedeana Kunze
Abundance

-dominance

\section{EBENACEAE}


Appendix 1. Continues

$$
\text { Family / Species }
$$

Diospyros texana Scheele

\section{EUPHORBIACEAE}

Bernardia myricaefolia (Scheele) Benth et Hook.

Croton fruticulosus Engelm. ex Torr.

FABACEAE

Acacia farnesiana (L.) Willd.

Prosopis glandulosa Torr. var. glandulosa

FAGACEAE

Quercus fusiformis Small

JUGLANDACEAE

Carya illinoinensis (Wangenh.) K.Koch

Juglans microcarpa Berland. var. microcarpa

MALVACEAE

Abutilon incanum (Link) Sweet

Allowissadula holosericea (Scheele) D.M.Bates

Malvastrum coromandelianum (L.) Garcke

Pavonia lasiopetala Scheele

MENISPERMACEAE

Cocculus carolinus (L.) DC.

MORACEAE

Morus celtidifolia Kunth

OLEACEAE

Fraxinus berlandieriana DC.

\section{PASSIFLORACEAE}

Passiflora foetida L. var. gossypiifolia (Desv. ex Ham.) Mast.

\section{PLATANACEAE}

Platanus occidentalis L. var. palmeri (Kuntze)Nixon et J. Poole ex Geerinck POACEAE

Aristida purpurea Nutt.

Chloris subdolichostachya C.Muell.

Dichanthium annulatum (Forssk.) Stapf
Specimen collection numbers

Life form

E 1857, C 2481

Tree

Shrub

Herb

E 1054, C 2482

C 2541, R 960

C 2543

E 1030, C 2483 R 954, V 8971

E 1029, C 2510, V 6076

E 1068, C 2511, R 1064, V 5994

E 1052

R 1247

E 1860

E 1843

E 1067, C 3473

C 2567, V 8947

E 1060, C 3727, R 1261, V 8964

E 1065, C 2460, R 1052, V 6002

E 1089

E 1851, C 3090

E 1854, C 2525
Tree

Tree

Tree

Abundant

Tree

Tree

Abundant

Rare

Herb

Herb

Herb

Herb

Vine

Rare

Tree

Scarce

Tree

Rare

Vine

Scarce

Tree

Rare

Frequent

(1)

Rare

Rare 
Appendix 1. Continues

Family / Species

Setaria parviflora (Poir.) Kerguélen

Tridens texanus (S. Watson) Nash

\section{RANUNCULACEAE}

Clematis drummondii Torr. et A.Gray

RHAMNACEAE

Condalia hookeri M.C.Johnst.

SALICACEAE

Salix nigra Marshall

SAPINDACEAE

Serjania incisa Torr.

SAPOTACEAE

Bumelia celastrina Kunth

Bumelia lanuginosa (Michx.) Pers. var. texana (Buckley) Cronquist SCROPHULARIACEAE

Leucophyllum frutescens (Berland.) I.M.Johnst.

SIMAROUBACEAE

Castela erecta Turpin subsp. texana (Torr. et A.Gray) Cronquist

\section{SMILACACEAE}

Smilax bona-nox L.

\section{STERCULIACEAE}

Melochia pyramidata L.

ULMACEAE

Celtis pallida Torr.

Celtis reticulata Torr.

Ulmus crassifolia Nutt.

VERBENACEAE

Phyla nodiflora (L.) Greene var. nodiflora

VITACEAE

Vitis cinerea (Engelm.) Engelm. ex Millardet
Specimen
collection numbers

Life form

E 1888, C 2447

C 3353

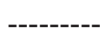

E 1072

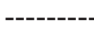

E 1842

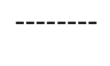

$-------$

E 1076, C 2547

Shrub

E 1087

E 1070, C 3784, R 1258, V 6075

E 1891, C 2590, R 1263

$$
\text { C 2267, R } 963
$$

E 1084, C 3473

E 1031

E 1039, C 2508, V 8900

E 1032, C 2529, R 1270, V 6069
Herb

Herb

Vine

Tree

Scarce

Scarce

Vine

Frequent

Herb

Scarce

Shrub

Herb

Scarce

Abundance -dominance

Scarce

Frequent

Scarce

Rare

Rare

Rare

Scarce

Scarce

Tree

Tree

Frequent

Rare

Vine

Scarce 